\title{
RJEŠENJE O OVRSI NA BRODU - DE LEGE LATA I RJEŠENJA DE LEGE FERENDA
}

\author{
UDK: 347. 79 (497.5) \\ Pregledni rad \\ Primljeno: 1. 3. 2016.
}

Podnošenjem prijedloga za ovrhu nadležnom sudu od strane ovrhovoditelja i donošenjem rješenja o ovrsi postupak ovrhe na brodu radi namirenja novčane tražbine prelazi iz faze predlaganja u praktičnu fazu realizacije, uz provedbu propisanih ovršnih radnji, sa osnovnim ciljem samog postupka-namirenjem vjerovnika iz prodajne cijene broda ostvarene sudskom prodajom. Rješenje o ovrsi na brodu regulira Pomorski zakonik člancima 856.-859. Dio odredbi, posebno članaka 856. i 857. ne pridonose pravnoj sigurnosti zainteresiranih strana postupka. Vidljive su i određene nedosljednosti i neusklađenosti zakonskih odredbi Ovršnog zakona i Pomorskog zakonika u odnosu na dostavu rješenja o ovrsi. Zabilježbom rješenja o ovrsi u praksi mogu nastati specifične situacije koje idu u korist zainteresiranim stranama. Zabilježba rješenja o ovrsi, odnosno trenutak od kojeg zaključak suda kojim se nalaže ta zabilježba proizvodi pravne učinke, ima presudan utjecaj na prvenstveni red prava na namirenje koje pripada ovrhovoditelju, ako u postupku sudjeluju dva ili više ovrhovoditelja. Taj trenutak od kojeg proizlaze pravni učinci odlučujući je za prvenstveni red prava na namirenje ovrhovoditelja i u slučaju zamolnice upućene nadležnom sudu za provedbu ovrhe, kao i kod prijedloga za ovrhu, ako je sud nadležan za donošenje rješenja o ovrsi i za provedbu tog rješenja. Neke trenutno važeće odredbe mogu biti uzrok nepotrebnih prijepora u slučaju postojanja više od jednog ovrhovoditelja. Sve su to razlozi da se takve odredbe, kao izvor određenih nedorečenosti, zamijene pravno efikasnijim rješenjima.

Ključne riječi: rješenje o ovrsi na brodu, dostava rješenja, zabilježba rješenja, namirenje više ovrhovoditelja

\section{UVOD}

Prihvaćanjem prijedloga za ovrhu na brodu koji je podnio ovrhovoditelj, nadležni sud donosi rješenje o ovrsi i pristupa praktičnoj provedbi postupka. ${ }^{1} \mathrm{PZ}$ navodi da rješenje o ovrsi prodajom broda sud dostavlja prema odredbama Ovršnog zakona o osobnoj dostavi strankama i svim osobama u čiju korist, prema podacima iz spisa, postoji kakvo založno pravo, pravo na namirenje, pravo osobne služnosti ili pravo prvokupa u pogledu broda koji je predmet ovrhe. ${ }^{2}$ Način dostavljanja

1 Pomorski zakonik Republike Hrvatske (u daljnjem tekstu PZ), Narodne novine br. 181/04, 76/07, 146/08, 61/11, 56/13 u članku 841. stavak 6. utvrđuje da ovrhu i osiguranje na brodu i teretu određuju $\mathrm{i}$ provode trgovački sudovi nadležni za pomorske sporove.

2 Odredbe čl.856.st.1. PZ 
rješenja o ovrsi (kao i ostalih pismena) utvrđen je odredbama članka 8. Ovršnog zakona. Dostava pravnoj osobi koja je upisana u sudski ili drugi upisnik obavlja se na adresu sjedišta upisanoga u upisnik (stavak 1.). Odredbe st.1. primjenjuju se i na fizičke osobe koje obavljaju upisanu djelatnost kad im se dostava obavlja u vezi s tom djelatnošću (stavak 3.). Fizičkoj osobi koja ne obavlja određenu upisanu djelatnost dostava se obavlja na adresi prebivališta u RH prema podacima koje će sud, odnosno javni bilježnik pribaviti iz evidencije MUP (stavak 4.). Ako dostava ne uspije na adresi iz stavaka 1. i 4. ovoga članka, dostava će se pokušati obaviti još jednom, u roku koji ne može biti kraći od 30 niti duži od 60 dana. Ako se ni ta ponovljena dostava ne uspije obaviti, dostava će se obaviti isticanjem pismena koje je trebalo dostaviti na mrežnoj stranici e-oglasna ploča sudova. Smatrat će se da je dostava obavljena istekom osmoga dana od dana isticanja pismena na mrežnoj stranici e-oglasna ploča sudova (stavak 6.) ${ }^{3}$

Iako odredbe navode sve zainteresirane osobe kojima se dostavlja rješenje o ovrsi, samo međusobni pravni odnos i status stranaka (ovrhovoditelja i ovršenika) predstavlja temelj i krucijalni je faktor cjelokupnog postupka ovrhe radi namirenja novčane tražbine, pa tako i onog na brodu. Koliko je taj odnos kompleksan, specifičan i problematičan pokazuje početna faza postupka-dostavljanje rješenja o ovrsi. Kako se postupak dalje razvija tako raste i problematika a veliku ulogu u tome imaju neke nepotpune odredbe ovršnog dijela PZ (članci 841.-927.). ${ }^{4}$ Ovršenikov položaj je posebno težak, jer je njegova imovina (brod) u postupku prisilne sudske prodaje pa je ovrha pravno stanje koje može ugroziti njegovu egzistenciju kao i članova njegove uže obitelji. Iako je krivac za pokretanje ovrhe zbog nenamirene tražbine ovrhovoditelju, ovršenik ima sva prava da bude neupitno obaviješten o pokrenutom postupku, putem dostavljenog rješenja o ovrsi, u skladu s ostvarenjem načela zaštite dužnika kako navodi članak $6.0 Z .{ }^{5}$ Međutim, u praksi dostava rješenja ovršeniku može izazvati nejasnoće zbog nedosljednosti i neusklađenosti zakonskih odredbi OZ i PZ koje se odnose na dostavu. Isto tako, neke odredbe PZ kojima se utvrđuje zabilježba rješenja o ovrsi pokazuju svoje manjkavosti u slučaju da su postupak pokrenula dva ili više ovrhovoditelja. ${ }^{6}$ Sve su to razlozi da zakonodavac svojim pravnim mehanizmima ukloni uočene nedostatke i tako omogući nesmetano odvijanje ovršnog postupka.

3 Ovršni zakon, NN 112/12,25/13,93/14 (u daljnjem tekstu OZ).

4 O cjelokupnoj problematici koja prati ovršnu prodaju broda po odredbama PZ vidi Dean Vuleta, Ovršna prodaja broda de lege ferenda, Zbornik radova Pravnog fakulteta u Splitu, god.50, br.4/2013.,str.993.-1015. nepovoljna.

6 Takav slučaj je kad ovrhu pokrenu privilegirani vjerovnici koji ne moraju znati jedan za drugoga jer o njihovim tražbinama ne postoje podaci u upisniku brodova. $\mathrm{O}$ tome infra, naslov 4 . 


\section{DOSTAVA RJEŠENJA O OVRSI OVRŠENIKU}

Odredbe članka 856.st.1.PZ navode da se rješenje o ovrsi prodajom broda dostavlja zainteresiranim stranama postupka (dakle i ovršeniku) prema odredbama $\mathrm{OZ}$ o osobnoj dostavi. Dostava pismena po odredbama starog $\mathrm{OZ}^{7}$ je pokazala određene manjkavosti u sudskoj praksi kad se radilo o fizičkoj osobi koja ne obavlja upisanu djelatnost, odnosno vlasniku broda-ovršeniku čiji brod nije upisan u upisnik brodova. ${ }^{8}$ Takvu osobu-ovršenika koji ne obavlja upisanu djelatnost odredbe članka 8. OZ koje utvrđuju dostavu nisu niti spominjale. Problematika nije bila vezana za pravne i fizičke osobe koje obavljaju upisanu djelatnost (vlasnici-ovršenici čiji je brod upisan u upisnik brodova) jer im se dostava (prema čl.8.) obavlja na adresu sjedišta odnosno prebivališta. Ako dostava ne uspije na takav način obavit će se isticanjem rješenja na oglasnoj ploči suda i smatrat će se da je dostava obavljena istekom osmog dana od isticanja rješenja na oglasnoj ploči suda. Ovršeniku čiji brod nije upisan u upisnik brodova, ali mu je poznato prebivalište ili boravište iz prijedloga za ovrhu koji je podnio ovrhovoditelj, rješenje o ovrsi dostavlja se osobnom dostavom a ne putem oglasne ploče suda. Takva situacija mogla je biti izvor zlouporabe od strane ovrhovoditelja. Naime, stari OZ je tolerirao da adresu kao i ostale podatke ovršenika navodi ovrhovoditelj. Dakle, ako je ovrhovoditelj svjesno ili nesvjesno naveo krivu adresu ovršenika, odnosno adresu na kojoj više ne živi, rješenje o ovrsi ovršenik često nije ni dobio te se nije imao priliku žaliti, a tada je rješenje o ovrsi postalo pravomoćno. ${ }^{9}$

Poučen problematikom dostave iz sudske prakse ovršne prodaje nekretnine, a s obzirom na mobilnost broda, zakonodavac je odredbama PZ pokušao ublažiti takvo stanje u pogledu ovršne prodaje broda. ${ }^{10}$ Mada je brod po svojim imovinskopravnim osobinama nedvojbeno pokretna stvar koju krasi izuzetna mobilnost, u stvarnopravnim raspolaganjima se tretira poput nekretnine na kopnu i podvrgava knjižnom režimu. ${ }^{11}$ Iz tih razloga odredbe o dostavi rješenja o ovršnoj prodaji nekretnine vrijede i u slučaju ovršne prodaje broda kako navodi čl.856.st.1. PZ. Odredbe čl.856.st.3. PZ navode ovlast suda da dostavi rješenje o ovrsi zapovjedniku

7 Stari OZ, na snazi do donošenja novele NN 93/14 kojom se mijenjaju pravila o dostavi pismena (rješenja o ovrsi). O novim pravilima dostave u čl.8. OZ vidi, supra naslov 1.

8 Prema čl.191.st.1.i 3. PZ ne može se upisati u hrvatski upisnik brodova brod koji je upisan u inozemni upisnik brodova. Ne može se upisati u hrvatski upisnik brodova i brod koji je stariji od najviše dopuštene starosti za određene vrste brodova.

9 Tek prema odredbama čl.8.st.4. novog OZ (NN 93/14) rješenje o ovrsi mora sadržavati neupitnu adresu fizičke osobe-ovršenika koja ne obavlja upisanu djelatnost. Adresu pribavlja sud odnosno javni bilježnik iz evidencije MUP.

10 Odredbe čl.856.st.3.PZ

11 O imovinskopravnim osobinama broda vidi Ivo Grabovac, Plovidbeno pravo Republike Hrvatske, Književni krug, Split, 2003.str.458. 
Mr. sc. Dean Vuleta: Rješenje o ovrsi na brodu - de lege lata i rješenja de lege ferenda Zbornik radova Pravnog fakulteta u Splitu, god. 53, 4/2016., str. 1039.-1052.

broda, odnosno ako je zapovjednik napustio brod postavljenom privremenom zastupniku ovršenika, u slučaju ako je boravište ovršenika nepoznato ili ako se on nalazi u inozemstvu. Međutim, ove odredbe ne pridonose pravnoj sigurnosti ovršenika koji bi morao biti u kontaktu sa svojim eventualnim zastupnicima, a što u slučaju imenovanih osoba može biti teško ostvarivo. Zapovjednik broda kao zastupnik i ovlaštena osoba brodara brine se za ostvarenje ugovorenog plovidbenog pothvata $^{12}$, a u nekim slučajevima ovlašten je i pokrenuti postupak i poduzimati procesne radnje pred stranim sudskim i upravnim tijelima. ${ }^{13}$ Osim toga, velika većina brodara angažira pomorsku agenciju kao servis zapovjedniku i posadi broda izvan sjedišta brodara s ciljem lakšeg ostvarenja pomorskog pothvata. ${ }^{14}$ Sve su to razlozi da zapovjednik broda ne mora biti u stalnom kontaktu s vlasnikom brodaovršenikom, pogotovo što brodar kao nositelj plovidbenog pothvata ne mora biti i vlasnik broda-ovršenik. U praksi vlasnik broda je obično i brodar, ali to može biti i naručitelj prijevoza iz brodarskog ugovora, odnosno zakupac broda. ${ }^{15}$ Ako zapovjednik broda nije u stalnom kontaktu s vlasnikom broda ne mora biti u situaciji da ga obavijesti o dostavljenom rješenju o ovrsi.

Postavljanje odgovarajuće osobe kao privremenog zastupnika ovršenika kojemu će sud dostaviti rješenje o ovrsi, ako je zapovjednik napustio brod, izaziva još veće nedoumice. Odredbama nije utvrđeno tko može biti takva osoba, s kakvim kvalifikacijama i ovlaštenjima, pa su moguće zlouporabe od strane takve osobe, pogotovo što ovršenik niti ne mora znati za privremenog zastupnika i biti u kontaktu s njim.

Suočen sa posljedicama nepotpunih odredbi i mnogim zlouporabama na štetu ovršenika u sudskoj praksi ovršnih sudova, zakonodavac pokreće pravne mehanizme te odredbama novog OZ rješava u potpunosti pitanje dostave pismena u ovršnom postupku i time više štiti ovršenika od odredbi starog zakona. ${ }^{16}$ Bitna okolnost je navođenje fizičke osobe u čl.8.st.4. koja ne obavlja upisanu djelatnost

12 Vidi Jakša Barbić, Zapovjednik broda-punomoćnik brodara po zaposlenju, Zbornik Pravnog fakulteta u Zagrebu, Vol.58 no.1-2, 2008.,str.29.-33. Prema članku 156. st. 1. PZ-a. zapovjednik broda, kao zastupnik brodara, ovlašten je u njegovo ime i za njegov račun u mjestu izvan sjedišta brodara sklapati ugovore o spašavanju i pravne poslove potrebne za izvršenje putovanja i u mjestu izvan sjedišta brodara u kojem nema ovlaštenog predstavnika brodara sklapati ugovore o pomorskim plovidbenim poslovima, osim brodarskog ugovora na vrijeme za cijeli brod.

13 Prema stavku 2. istog članka zapovjednik broda ovlašten je kao zastupnik brodara pokretati pred stranim sudskim i upravnim tijelima postupak radi zaštite brodarovih prava i interesa iz stavka 1. ovoga članka i u tom postupku poduzimati procesne radnje.

14 Podrobnije o djelokrugu pomorskog agenta vidi Vojislav Borčić, Međunarodni i hrvatski propisi o pomorskom agentu, Udruga pomorskih agenata, Rijeka, 1999. PZ utvrđuje djelokrug pomorskog agenta u Glavi III Ugovor o pomorskoj agenciji, članci 674.-683.

15 O statusu zakupca broda vidi Vesna Skorupan Wolff, Pravno uređenje zakupa broda u hrvatskom pravu, Zbornik Pravnog fakulteta u Zagrebu, br.58 (1-2),2008.,str.537.-540.

16 Članak 8. OZ, NN 93/14 
(vlasnik čiji brod nije upisan u upisnik brodova), kome se rješenje o ovrsi dostavlja na adresu prebivališta pribavljenu od strane suda odnosno javnog bilježnika iz evidencije MUP-a. Stare odredbe nisu spominjale takvu osobu. Novitet je i uvođenje dodatnih odredbi u st.6. tog istog članka u slučaju neuspjele dostave na adresu čime zakonodavac kvalitetno i neupitno rješava dostavu pismena svim sudionicima postupka. ${ }^{17}$

Međutim, nove odredbe čl.8. OZ koje kvalitetno rješavaju staru problematiku dostave pismena u ovršnom postupku nose sa sobom i novu problematiku koja može izazivati nedoumice u sudskoj praksi ovršne prodaje brodova. One su neusklađene sa odredbama čl.856.st.3. PZ koje utvrđuju dostavu rješenja o ovrsi zapovjedniku broda i postavljanje privremenog zastupnika ovršenika pod određenim uvjetima. Naime, do donošenja novele OZ (NN 93/14) dostava je u nekim slučajevima sudske prakse bila upitna, jer nije utvrđena fizička osoba koja ne obavlja upisanu djelatnost (vlasnik čiji brod nije upisan u upisnik brodova), pa je zakonodavac odredbama PZ dopunio dostavu, zbog specifičnosti ovršne prodaje broda, time što navodi nove osobe kojima se može dostaviti rješenje o ovrsi ako je boravište ovršenika nepoznato ili se ovršenik nalazi u inozemstvu. Novi OZ posljednjom novelom u potpunosti rješava dostavu pismena (rješenja o ovrsi) i time prestaje potreba, pod bilo kojim uvjetima, dostave rješenja o ovrsi zapovjedniku broda ili imenovanja druge odgovarajuće osobe kao privremenog zastupnika ovršenika, ako je zapovjednik napustio brod. S obzirom da čl.856.st.1. PZ navodi da rješenje o ovrsi prodajom broda sud dostavlja prema odredbama Ovršnog zakona (čl.8.), koje su sada jasne i neupitne, potrebno je, de lege ferenda, brisati stavak 3.čl.856. PZ jer te odredbe u novim uvjetima određenja dostave pismena postaju irelevantne odnosno pravno neodržive.

\section{UČINAK ZABILJEŽBE RJEŠENJA}

Učinak zabilježbe rješenja o ovrsi regulira čl.857. PZ. Kad donese rješenje o ovrsi na brodu upisanom u upisnik brodova koji se vodi pri lučkoj kapetaniji, sud će po službenoj dužnosti odrediti da se to rješenje zabilježi u upisnik brodova (stavak

17 Ako dostava ne uspije na adresi, dostava će se pokušati obaviti još jednom, u roku koji ne može biti kraći od 30 niti duži od 60 dana. Ako se ni ta ponovljena dostava ne uspije obaviti, dostava će se obaviti isticanjem pismena koje se trebalo dostaviti na mrežnoj stranici e-oglasna ploča sudova. Smatrat će se da je dostava obavljena istekom osmoga dana od dana isticanja pismena na mrežnoj stranici e-oglasna ploča sudova. Stare odredbe OZ nisu predviđale dostavu pismena u dodatnim rokovima niti putem interneta. Ako dostava na adresu ne uspije obavit će se isticanjem pismena na oglasnoj ploči suda. Smatrat će se da je dostava obavljena istekom osmoga dana od dana isticanja pismena na oglasnoj ploči suda. 
Mr. sc. Dean Vuleta: Rješenje o ovrsi na brodu - de lege lata i rješenja de lege ferenda Zbornik radova Pravnog fakulteta u Splitu, god. 53, 4/2016., str. 1039.-1052.

1). ${ }^{18}$ Ako donese rješenje o ovrsi na brodu koji nije upisan u upisnik brodova, sud će po službenoj dužnosti odrediti da se obavi pljenidbeni popis broda (stavak 2). ${ }^{19}$ Ovrhovoditelj u čiju je korist zabilježba odnosno popis učinjen ima prvenstvo u pogledu namirenja svoje ovršne tražbine i sporednih tražbina prema svakoj drugoj osobi koja kasnije stekne kakvu hipoteku na brodu ili slično pravo na brodu ili koja ostvari pravo na namirenje. Učinak zabilježbe iz st.1. i popisa iz st.2. sastoji se u tome da se prodaja radi namirenja tražbine ovrhovoditelja može provesti protiv svake osobe koja kasnije stekne pravo vlasništva nad brodom koji je predmet prodaje (stavak 3). Nakon zabilježbe ovrhe nije dopušten upis promjene prava vlasništva druge osobe koja je od ovršenika kupila brod poslije zabilježbe rješenja o ovrsi (stavak 4), mada je takva kupoprodaja moguća i pravno dopuštena. Međutim, novi vlasnik zauzima mjesto prethodnog vlasnika-ovršenika i sam postaje ovršenik. Sve radnje poduzete prije toga ostaju na snazi, te novi vlasnik broda- ovršenik ne može u postupku poduzimati one radnje koje ne bi mogao poduzeti prijašnji vlasnik da do promjene vlasništva nije došlo (stavak 5).

Dinamičnost i gospodarski značaj pomorskog prometa razlog su mnogih pravnih odnosa u koje ulaze ili mogu ući zainteresirane strane, a nisu dovoljno regulirani odredbama. Tako su u praksi mogući slučajevi kad ovršenik proda brod nakon zabilježbe rješenja o ovrsi, a novi vlasnik preuzima sva prava i obveze u pogledu broda i zauzima mjesto ovršenika. Pravni interes u ovome poslu mogu imati sve zainteresirane strane u ovršnom postupku. Prethodni vlasnik kao ovršenik prodaje brod novom vlasniku po tržišnoj cijeni ili drugoj odgovarajućoj cijeni koja zasigurno

18 Brod je kao plovni objekt nedvojbeno pokretna stvar koju krasi izuzetna mobilnost u promjeni lokacije (luke). Pokretnine su one pojedinačno određene stvari koje karakterizira mogućnost premještanja s jednog mjesta na drugo a da im se ne povrijedi bit (supstanca). Politički i gospodarski razlozi dovode do potrebe da se brodovi vlastite državne pripadnosti evidentiraju u upisniku brodova, da se u stvarnopravnim raspolaganjima tretiraju poput nekretnina na kopnu i podvrgavaju knjižnom režimu u stvarnopravnim odnosima. Brodovi se tako u pravnom smislu imobiliziraju. Politički razlog je činjenica da je pravo vlasništva tijesno povezano s pravom državne pripadnosti broda, a o državnoj pripadnosti broda često ovisi koji će pravni poredak biti mjerodavan u slučaju spora. Gospodarski razlog za upisni režim sadržan je u velikoj vrijednosti broda. O imovinskopravnim karakteristikama brodova kao ,specifičnim nekretninama“ vidi Jasenko Marin, Stvarnopravno uređenje za plovila unutarnje plovidbe, Poredbeno pomorsko pravo, god.48.(2009),163,str.34. i 35.

19 Za brodove koji nisu upisani u upisnik brodova (prema čl.191.st.1.i st.3 PZ), nakon donošenja rješenja o ovrsi, a prije prodaje na javnoj dražbi, sud određuje obavljanje pljenidbenog popisa koji u stvarnosti znači zapljenu broda. Zbog velike mobilnosti broda kao pokretne stvari i mogućnosti da u kratkom vremenu promijeni više lokacija (luka), a kako nije podvrgnut knjižnom režimu, za tu ovrhu mjesno je nadležan u pravilu sud na čijem se području, prema naznaci u prijedlogu za ovrhu, nalazi brod (čl.845.PZ). Iznimno, ako se u vrijeme podnošenja prijedloga za ovrhu na brodu koji nije upisan u upisnik brodova ne zna da li se brod nalazi u teritorijalnom moru ili unutarnjim morskim vodama RH, ovrhovoditelj može prijedlog za ovrhu podnijeti bilo kojem stvarno nadležnom sudu. Rješenje o ovrsi ovrhovoditelj može radi provedbe ovrhe podnijeti stvarno nadležnom sudu na području kojega se nađe brod (čl.846.PZ). O problematici sudske nadležnosti vidi opširnije Dean Vuleta, Nadležnost i ovlasti suda u postupku prisilne prodaje broda-de lege lata i rješenja de lege ferenda, Zbornik radova Pravnog fakulteta u Splitu,god.51 br.3/2014.,str.715.-726. 
ne bi bila postignuta na javnoj dražbi i rješava se statusa ovršenika. ${ }^{20}$ Prethodni vlasnik ima najveći pravni interes za ovakvu raspoložbu, jer je svjestan da će se u slučaju nastavka provedbe ovrhe teško okoristiti ostatkom iznosa preostalim nakon sudske prodaje broda i namirenja troškova postupka i tražbina vjerovnika. Novi vlasnik je ugovorio jedan ili više plovidbenih pothvata, premda je svjestan postupka ovrhe koji je u tijeku i rizika koji on donosi, ali računa da će dobivenim iznosom od eksploatacije broda, nakon što podmiri sve dotadašnje troškove postupka i tražbine vjerovnika, bez problema podmiriti troškove kupnje broda. Uporište za ovakvu raspoložbu novog vlasnika nalazi se u odredbama čl.866. PZ-a. ${ }^{21}$ Vjerovnicima koji na brodu imaju kakav stvarnopravni teret je pravni interes da brzo namire svoje tražbine, prije dugotrajnog i neizvjesnog ovršnog postupka i javne dražbe, pa se nemaju razloga protiviti ovakvoj raspoložbi. Sud će gotovo sigurno odobriti jedno ili više putovanja ako zainteresirana osoba (novi vlasnik broda) zadovolji uvjete iz čl.866. PZ-a i dokaže sudu pravnu osnovu za poduzimanje putovanja (pismeni ili usmeni ugovor s naručiteljem prijevoza). Ovakvu raspoložbu, kao realnu i ostvarivu u sudskoj praksi u korist svih zainteresiranih strana postupka, potrebno je dodatno utvrditi odredbama kroz nadopunu članka 857. Prvenstveno se to odnosi na odredbama danu ovlast od strane zakonodavca trećoj osobi (kupcu koji je kupio brod od ovršenika nakon zabilježbe rješenja o ovrsi) po kojoj može, ako to želi, izvršiti upis promjene prava vlasništva u svoju korist, bez obzira što bi se taj upis obavio nakon zabilježbe ovrhe. Ako odredbe st.3.čl.857. već navode da se ovrha može provesti protiv svake osobe koja kasnije stekne pravo vlasništva nad brodom koji je predmet ovrhe (nakon zabilježbe rješenja), i st.5. istog članka da promjena vlasnika broda nakon zabilježbe ovrhe ne sprječava da se taj postupak nastavi protiv novog vlasnika kao ovršenika, čime su u potpunosti zaštićeni vjerovnici, onda nema nikakvog razloga da se kupcu ne dopusti upis promjene prava vlasništva u svoju korist. Ovakva raspoložba nije utemeljena na zlouporabi ovršenika. Time bi se kupcu broda ojačala pozicija u ugovaranju plovidbenih pothvata tijekom postupka ovrhe. Stoga bi stavak 4.članka 857. PZ trebalo de lege ferenda nadopuniti.

20 Tržišna cijena broda formira se prema odnosu ponude i potražnje na kupoprodajnom tržištu brodova.

${ }_{21}$ Sud može na prijedlog zainteresirane osobe dopustiti da brod u tijeku ovrhe poduzme jedno ili više putovanja, ako za to postoje posebno opravdani razlozi i nakon što sasluša stranke i poznate vjerovnike koji na brodu imaju kakav stvarnopravni teret. Sud neće dopustiti putovanje ako nije sklopljen ugovor o osiguranju broda, uz uvjete koje sud smatra prikladnim, i ako predlagatelj putovanja ne dade odgovarajuće osiguranje raspoloživo i prenosivo u korist vjerovnika za štetu koja bi za njih iz toga mogla proisteći. Radi saslušanja stranaka i ostalih vjerovnika sud će zakazati ročište ili će ovlaštenim osobama pisano priopćiti prijedlog i uvjete uz koje se traži dozvola za poduzimanje putovanja, uz poziv da se o prijedlogu izjasne u roku od tri dana od dana dostave poziva. Ako koja od pozvanih osoba ne dođe na ročište, odnosno ako se u roku od tri dana ne izjasni o prijedlogu, smatrat će se da pristaje na to da se predloženo putovanje poduzme. Osoba na čiji je prijedlog putovanje dopušteno dužna je, na zahtjev suda, predujmiti troškove putovanja. Ako to ne učini u roku koji sud odredi, putovanje se neće poduzeti. 
Mr. sc. Dean Vuleta: Rješenje o ovrsi na brodu - de lege lata i rješenja de lege ferenda Zbornik radova Pravnog fakulteta u Splitu, god. 53, 4/2016., str. 1039.-1052.

Stavak 4. članka 857. glasi:

(4) Nakon zabilježbe ovrhe nije dopušten upis promjene prava vlasništva utemeljen na raspoložbi ovršenika, bez obzira kad je ta raspoložba poduzeta.

Stavak 4. članka 857. treba glasiti:

(4) Nakon zabilježbe ovrhe nije dopušten upis promjene prava vlasništva utemeljen na raspoložbi ovršenika, s namjerom da se onemogući namirenje tražbine ovrhovoditelja, ${ }^{22}$ bez obzira kad je ta raspoložba poduzeta. Kupcu koji je kupio brod od ovršenika nakon zabilježbe ovrhe dopušten je upis promjene prava vlasništva u svoju korist, ako je ta raspoložba u skladu s odredbama drugih zakona Republike Hrvatske i u skladu s odredbama članka 866. ovoga Zakonika.

\section{PRVENSTVENI RED NAMIRENJA OVRHOVODITELJA}

U postupku prisilne prodaje broda rijetko se namiruje samo jedan vjerovnik koji je pokrenuo ovrhu kao ovrhovoditelj. Obično je brod pod ovrhom opterećen s više tražbina različitih provenijencija , pa se u postupku namiruju i založni vjerovnici koji nisu predložili ovrhu. Hipotekarni vjerovnici namiruju se iz diobne mase i kada nisu prijavili svoje tražbine, a privilegirani vjerovnici samo ako su prijavili svoje tražbine i to najkasnije na ročištu za prodaju broda. ${ }^{23}$ Vjerovnici se podmiruju prema redu prvenstva navedenom u članku 912. PZ-a. ${ }^{24}$

Međutim, ovrhu mogu pokrenuti i više od jednog ovrhovoditelja koji ne moraju znati jedan za drugog (npr. dva ili više privilegiranih vjerovnika o kojima ne postoje podaci u upisniku brodova). Intencija je zakonodavca, u smislu stavaka 6. i 7. čl.857. PZ da je za prvenstveni red prava na namirenje koje pripada ovrhovoditelju odlučujući trenutak kad zabilježba rješenja o ovrsi, odnosno obavljeni pljenidbeni popis broda proizvode pravne učinke prema drugima. To znači da ovrhovoditelj

22 Takav slučaj bi bio npr. upis promjene prava vlasništva u korist bliskog člana obitelji ovršenika.

23 Razlog tome je što hipoteka na brodu nastaje i proizvodi pravne učinke upisom u upisnik brodova, a za nastanak i pravno djelovanje pomorskog privilegija nije potreban upis u upisnik brodova, mada je zakonodavac dao pomorskom privilegiju prvenstvo u namirenju pred svim drugim tražbinama, osim sudskih troškova koji se namiruju prije razdiobe kupovnine. Dakle, sud ne mora biti upoznat sa brojem pomorskih privilegija koji opterećuju brod, već samo s onim tražbinama koje su upisane u upisnik brodova.

24 1) Republika Hrvatska za tražbine s osnova članaka 171., 840.1j, 840.m i 840.n, 2)vjerovnici čije su tražbine osigurane pomorskim privilegijem, 3)vjerovnici prava zadržaja iz čl.437., 4)vjerovnici čije su tražbine osigurane hipotekom na brodu, 5)ostali vjerovnici. Troškovi nastali u tijeku postupka prodaje broda namiruju se prije razdiobe kupovnine, pa i bilo koje tražbine Republike Hrvatske. 
u čiju je korist prije doneseno rješenje o ovrsi ili obavljen pljenidbeni popis broda ima prvenstvo u namirenju pred drugim ovrhovoditeljem, ili više njih, koji se kasnije pojave u istom ovršnom postupku. Međutim, u slučaju postojanja više od jednog ovrhovoditelja moguće su situacije koje mogu otežati namirenje tražbine ovrhovoditelja. Takve situacije nisu rezultat pogrešnog postupanja suda ili ovrhovoditelja nego utjecaj vanjskog faktora nakon donesenog rješenja o ovrsi ili obavljenog popisa. Nakon što primi prijedlog za ovrhu od strane ovrhovoditelja nadležni sud donosi rješenje o ovrsi i po službenoj dužnosti određuje da se to rješenje zabilježi u upisnik brodova (st.1.čl.857.), odnosno da se obavi pljenidbeni popis broda (st.2.čl.857.). Zaključak kojim se nalaže zabilježba rješenja sud daje službi dostave (pošti), a ona dostavlja to rješenje tijelu koje vodi upisnik brodova. Isto tako, u slučaju broda koji nije upisan u upisnik brodova, nadležni sud za donošenje rješenja o ovrsi daje zamolnicu za provođenje pljenidbenog popisa službi dostave, a ona upućuje tu zamolnicu sudu nadležnom za provedbu ovrhe. Kad kasnije primi prijedlog za ovrhu od strane drugog ovrhovoditelja (ili više njih) nadležni sud će obaviti istu zakonsku proceduru. $\mathrm{O}$ toj proceduri ovisi prvenstveni red namirenja koji pripada ovrhovoditelju, odnosno ovrhovoditelj u čiju je korist prije doneseno rješenje o ovrsi treba imati prvenstvo u namirenju pred drugim ovrhovoditeljem (ovrhovoditeljima) u čiju je korist kasnije doneseno rješenje o ovrsi. Taj prvenstveni red prava na namirenje koje pripada ovrhovoditelju utvrđuje PZ odredbama koje se nisu pokazale kao najbolje rješenje, posebno odredbe koje su vrijedile do donošenja novele 56/13, pa su u praksi mogući prijepori i nepotrebne parnice između ovrhovoditelja. Tek je stupanjem na snagu novele PZ-a (Narodne novine br. 56/13) zakonodavac pokušao popraviti stanje, ali u tome nije uspio do kraja, jer je u odredbe unio samo sitne korekcije koje su neznatno popravile postojeću situaciju. Tako je PZ, NN 181/04,76/07,146/08,61/11 do donošenja novele 56/13 u stavku 6.čl.857. utvrdio da je za prvenstveni red koji pripada ovrhovoditelju odlučujući trenutak kad je tijelu koje vodi upisnik brodova podnesen zaključak suda kojim se nalaže zabilježba rješenja o ovrsi odnosno kada je obavljen pljenidbeni popis broda. U stavku 7. je utvrdio da ako predmet ovrhe nije upisan u upisnik brodova, red prvenstva određuje se prema trenutku kad zamolnica za provođenje popisa stigne sudu nadležnom za provođenje ovrhe, odnosno ako je taj sud nadležan za donošenje rješenja o ovrsi-prema trenutku kad tom sudu stigne prijedlog za ovrhu. 
Mr. sc. Dean Vuleta: Rješenje o ovrsi na brodu - de lege lata i rješenja de lege ferenda Zbornik radova Pravnog fakulteta u Splitu, god. 53, 4/2016., str. 1039.-1052.

\subsection{Prvenstveni red namirenja prije novele br. 56/13}

Služba dostave (pošta) svojim nenamjernim propustom može biti uzrok nepotrebnih prijepora među ovrhovoditeljima. ${ }^{25}$ Kad zaključak suda kojim se nalaže zabilježba rješenja o ovrsi ovrhovoditelja koji je prije stekao pravo na namirenje (jer je u njegovu korist prije doneseno rješenje o ovrsi) dostavom iz nepoznatog razloga stigne kasnije tijelu koje vodi upisnik brodova nego zaključak suda koji se odnosi na ovrhovoditelja koji je kasnije stekao pravo na namirenje (jer je u njegovu korist kasnije doneseno rješenje o ovrsi) dolazi do sporne situacije. Razlog takve dostave mogu biti vremenske neprilike ili obični nemar dostavljača. U tom slučaju ovrhovoditelju koji je kasnije stekao pravo na namirenje pripada prvenstvo u namirenju, prema odredbama stavka 6. članka 857., zato što je zaključak suda o zabilježbi ovrhe u njegovu korist prije podnesen tijelu koje vodi upisnik brodova nego zaključak suda u korist ovrhovoditelja koji bi trebao imati stvarno i pravno prvenstvo u namirenju. Isto je moguće u slučaju broda koji nije upisan u upisnik brodova. Sud koji je nadležan za donošenje rješenja o ovrsi donese rješenje o ovrsi na prijedlog prvog ovrhovoditelja, napiše zamolnicu za provođenje popisa sudu nadležnom za provedbu ovrhe, u korist tog ovrhovoditelja koji bi trebao imati stvarno i pravno prvenstvo u namirenju, i daje je službi dostave koja upućuje zamolnicu sudu nadležnom za provedbu ovrhe. Nakon toga na prijedlog drugog ovrhovoditelja sud ponovi istu zakonsku proceduru. Međutim, problem nastaje kad zamolnica u korist prvog ovrhovoditelja, koja je prva upućena, stigne kasnije tom sudu nego zamolnica u korist drugog ovrhovoditelja, koja je kasnije upućena, propustom službe dostave. Ovrhovoditelj koji ne bi trebao imati prvenstvo u namirenju, prema odredbama stavka 7. članka 857., ima to prvenstvo jer je zamolnica u njegovu korist stigla prije sudu nadležnom za provedbu ovrhe. Ako je sud nadležan za donošenje rješenja o ovrsi i za provedbu tog rješenja, red prvenstva određuje se prema trenutku kad tom sudu stigne prijedlog za ovrhu. Opet može doći do situacije da prijedlog za ovrhu jednog ovrhovoditelja, koji je prije upućen nadležnom sudu nego prijedlog za ovrhu drugog ovrhovoditelja, dođe kasnije tom sudu propustom službe dostave. Drugi ovrhovoditelj koji ne bi trebao imati stvarno i pravno prvenstvo u namirenju, prema odredbama stavka 7., ima to prvenstvo jer je njegov prijedlog za ovrhu stigao prvi nadležnom sudu,. U praksi može doći do situacije koja bi narušila jedno od osnovnih načela svakog pravnog sustava-načelo pravičnosti.

25 O dostavi pismena preko pošte vidi Nikola Bazianec, Uručenje sudskih pismena putem pošte, Trgovačko ugovorno pravo, Informator, 6/2000,str.6.-8. 
Mr. sc. Dean Vuleta: Rješenje o ovrsi na brodu - de lege lata i rješenja de lege ferenda Zbornik radova Pravnog fakulteta u Splitu, god. 53, 4/2016., str. 1039.-1052.

\subsection{Prvenstveni red namirenja poslije novele br. $56 / 13$}

Zakonodavac je svjestan takve situacije pokušao popraviti stanje dodatnim odredbama PZ-a. ${ }^{26} \mathrm{U}$ stavku 6.čl.857. utvrđuje prvenstveni red prava na namirenje koje pripada ovrhovoditelju na jednak način kao i prethodne novele PZ-a. Za prvenstveni red prava na namirenje koje pripada ovrhovoditelju, u slučaju broda upisanog u upisnik brodova, odlučujući je trenutak kad je tijelu koje vodi upisnik brodova podnesen zaključak suda kojim se nalaže zabilježba rješenja o ovrsi. U stavku 7. napušta rješenja prethodnih novela PZ-a. Ako predmet ovrhe nije upisan u upisnik brodova, red prvenstva određuje se prema trenutku kad je zamolnica za provođenje popisa upućena sudu nadležnom za provođenje ovrhe, odnosno ako je taj sud nadležan za donošenje rješenja o ovrsi prema trenutku kad je taj sud odredio obavljanje pljenidbenog popisa. Međutim, ponuđena rješenja nisu dostatna i samo djelomično otklanjaju postojeću problematiku. Nova odredba je u slučaju zamolnice, pa je za prvenstveni red prava na namirenje koji pripada ovrhovoditelju sada odlučujući trenutak kad je zamolnica za provođenje popisa upućena sudu nadležnom za provođenje ovrhe, a ne trenutak kad ta zamolnica stigne sudu kao u prethodnim novelama PZ-a. Sada više ne može biti prijepora zbog propusta službe dostave, jer je za prvenstveni red jedino relevantan trenutak kad je sud napisanu zamolnicu dao službi dostave. Nije jasno zašto zakonodavac nije postupio na isti način, kad je sud nadležan za donošenje rješenja o ovrsi i za provedbu ovrhe na brodu koji nije upisan u upisnik, te utvrdio da je za prvenstveni red odlučujući trenutak kad je prijedlog za ovrhu upućen nadležnom sudu, odnosno predan službi dostave. U tom slučaju, kao i kod zamolnice, više nema prijepora zbog propusta službe dostave. Nova odredba po kojoj je za prvenstveni red odlučujući trenutak kad je sud nadležan za donošenje i provedbu rješenja o ovrsi odredio obavljanje pljenidbenog popisa, kao i stara odredba po kojoj je za prvenstveni red odlučujući trenutak kad je sudu stigao prijedlog za ovrhu, ne rješava problematiku dostave i eventualnih prijepora između ovrhovoditelja. Sud odlučuje o onom prijedlogu za ovrhu koji je prvi stigao i donosi rješenje o ovrsi, odnosno određuje obavljanje pljenidbenog popisa. Međutim, moguće je da propustom službe dostave prijedlog koji je prvi upućen stigne kasnije sudu, pa je kasnije obavljena i procedura do obavljanja pljenidbenog popisa. Ovrhovoditelj koji bi trebao imati prvenstvo u namirenju, jer je prvi uputio prijedlog, nema to prvenstvo jer je u njegovu korist kasnije doneseno rješenje o ovrsi i obavljen pljenidbeni popis. Prema tome, jedino logično rješenje po kojem bi se trebao utvrđivati prvenstveni red namirenja je trenutak kad je prijedlog za ovrhu upućen sudu nadležnom za donošenje rješenja o ovrsi i provedbu ovrhe, a ne trenutak kad je sud odredio obavljanje pljenidbenog

26 Pomorski zakonik, Narodne novine br. 56/13 
popisa broda. U slučaju zaključka suda kojim se nalaže zabilježba rješenja o ovrsi zakonodavac ostaje na prethodnim rješenjima pa je za prvenstveni red odlučujući trenutak kad je tijelu koje vodi upisnik brodova podnesen zaključak suda kojim se nalaže zabilježba rješenja o ovrsi. Rješenje je trebalo biti da je za prvenstveni red prava na namirenje koje pripada ovrhovoditelju odlučujući trenutak kad je tijelu koje vodi upisnik brodova upućen zaključak suda kojim se nalaže zabilježba rješenja o ovrsi. Problematika vezana za prvenstveni red namirenja, kad se u postupku pojavi više od jednog ovrhovoditelja, jednaka je u slučaju broda koji je upisan i u slučaju broda koji nije upisan u upisnik brodova, pa nije jasno zašto zakonodavac nije posegnuo za potpunim rješenjem cjelokupne problematike, već je samo riješio pitanje zamolnice.

Dakle, potpuno je jasno da postojeće odredbe, de lege ferenda, treba nadopuniti preciznijim određenjima kako bi se u sudskoj praksi izbjegli nepotrebni prijepori.

Stavak 6. članka 857. glasi:

(6) Za prvenstveni red prava na namirenje koji pripada ovrhovoditelju u smislu stavka 3. ovoga članka, odlučujući je trenutak kad je tijelu koje vodi upisnik brodova podnesen zaključak suda kojim se nalaže zabilježba rješenja o ovrsi u smislu stavka 1. ovoga članka.

Stavak 6. članka 857. treba glasiti:

(6) Za prvenstveni red prava na namirenje koji pripada ovrhovoditelju u smislu stavka 3. ovoga članka, odlučujući je trenutak kad je tijelu koje vodi upisnik brodova upućen zaključak suda kojim se nalaže zabilježba rješenja o ovrsi u smislu stavka 1. ovoga članka.

Stavak 7. članka 857. glasi:

(7) Ako predmet ovrhe nije upisan u upisnik brodova, red prvenstva u smislu stavka 3. ovoga članka određuje se prema trenutku kad je zamolnica za provođenje popisa upućena sudu nadležnom za provođenje ovrhe, odnosno ako je taj sud nadležan za donošenje rješenja o ovrsi-prema trenutku kad je taj sud odredio obavljanje pljenidbenog popisa.

Stavak 7. članka 857. treba glasiti:

(7) Ako predmet ovrhe nije upisan u upisnik brodova, red prvenstva u smislu stavka 3. ovoga članka određuje se prema trenutku kad je zamolnica 
Mr. sc. Dean Vuleta: Rješenje o ovrsi na brodu - de lege lata i rješenja de lege ferenda Zbornik radova Pravnog fakulteta u Splitu, god. 53, 4/2016., str. 1039.-1052.

za provođenje popisa upućena sudu nadležnom za provođenje ovrhe, odnosno ako je taj sud nadležan za donošenje rješenja o ovrsi-prema trenutku kad je tom sudu upućen prijedlog za ovrhu.

\section{ZAKLJUČAK}

Rješenje o ovrsi na brodu temeljna je isprava cjelokupnog ovršnog postupka, regulirana odredbama članaka 856.-859.PZ-a, pa kao takva ne bi smjela biti izvor pravne nesigurnosti i nedoumica. Neke odredbe članka 856. nejasne su i neusklađene s odredbama članka 8. OZ. Dio odredbi članka 857. ne odgovaraju više zahtjevima današnjeg pomorskog gospodarstva, a neke od njih mogu biti uzrok nepotrebnih parnica među zainteresiranim stranama ovršnog postupka. Kako bi se postojeće odredbe zamijenile pravno efikasnijim rješenjima, autor predlaže rješenja de lege ferenda:

1.Odredbe stavka 3.članka 856., nakon stupanja na snagu novele 93/14 OZ, postaju pravno irelevantne pa ih je potrebno brisati. Naime, člankom 8 . OZ neupitno rješava pitanje dostave pismena (rješenja o ovrsi) zainteresiranim stranama postupka.

2.Odredbe stavka 4.članka 857. treba nadopuniti na način da se kupcu koji je kupio brod od ovršenika nakon zabilježbe rješenja o ovrsi dopusti upis promjene prava vlasništva, pogotovo jer odredbe stavaka 3. i 5. istog članka dovoljno štite prava vjerovnika i onemogućavaju zlouporabu.

3.Odredbe stavka 6. i 7.članka 857. treba formulirati na drugačiji način. Po pitanju prvenstvenog reda namirenja koji pripada ovrhovoditelju, u slučaju pokrenute ovrhe od strane dva ili više ovrhovoditelja zakonodavac nije vodio računa o vanjskom faktoru koji može utjecati na doneseno rješenje o ovrsi, obavljeni pljenidbeni popis broda i prijedlog za ovrhu, odnosno na trenutak od kojeg te isprave proizvode pravne učinke. Taj vanjski faktor je služba dostave (pošta) čijim propustom može doći do poremećaja prvenstvenog reda namirenja među ovrhovoditeljima koji sudjeluju u istom ovršnom postupku. Potpunim rješenjem kojim bi se utvrdilo da je za prvenstveni red prava na namirenje koje pripada ovrhovoditelju odlučujući trenutak kad je lučkoj kapetaniji, odnosno sudu nadležnom za provedbu ovrhe ili sudu nadležnom za donošenje rješenja o ovrsi i provedbu tog rješenja upućena određena isprava (zaključak suda, zamolnica za popis, prijedlog za ovrhu), odnosno predana službi dostave, propust službe dostave postaje pravno irelevantna činjenica. Time bi se u sudskoj praksi spriječili eventualni prijepori i parnice između ovrhovoditelja. 
Mr. sc. Dean Vuleta: Rješenje o ovrsi na brodu - de lege lata i rješenja de lege ferenda Zbornik radova Pravnog fakulteta u Splitu, god. 53, 4/2016., str. 1039.-1052.

\section{A WRIT OF EXECUTION ON THE SHIP}

By submitting an application for enforcement of the competent Court by bailiffs and the adoption of a writ of execution, foreclosure proceedings on a ship for the settlement of monetary claims exceeds the stage of proposing the practical implementation phase, with the implementation of prescribed enforcement actions from the primary aim of the procedure itself-satisfaction of creditors from the selling price of the ship realized by judicial sale. A writ of execution on the board regulates Maritime Code Articles 856.-859. Some of the provisions, especially articles 856. and 857. do not contribute to legal certainty of stakeholders in the process. Visible and certain inconsistencies and discrepancies legal provisions of the Enforcement Act and the Maritime Code in relation to the delivery of the writ of execution. A recordation of a writ of execution in practice can occur specific situations in favor of the interested parties. A recordation of a writ of execution, ie the moment of the conclusion that the court ordering the recording of legal effect, has a decisive influence on the order of priority rights to the settlement belonging to the execution creditor, if in the procedure participate two or more judgment creditors. That moment from which arise legal effects is determining in the order of priority for the right to settle the judgment creditors in the case of requests made to the competent court for enforcement of execution, as well as proposals for enforcement if the court competent to issue the writ of execution and enforcement of the decision. Some currently valid provisions may be causing unnecessary controversy in the case of more than one execution creditor. All these are reasons that these provisions, as the source of certain understatements, should be replaced with legally more effective solutions.

Key words: a writ of execution on the ship, a delivery of the writ of execution, a recordation of a writ, a settlement of the judgment creditors 